\title{
FINANCIALIZATION OF ECONOMY, TAKING INTO ACCOUNT AGRIBUSINESS
}

\author{
Justyna Franc-Dąbrowska \\ Department of Finance of Warsaw University of Life Sciences - SGGW \\ Head of Department: dr hab. Mirosław Wasilewski, prof. SGGW
}

\begin{abstract}
Słowa kluczowe: ufinansowienie, agrobiznes
Key words: financialization, agribusiness

S y n o p s i s: Financialization of economy is taking place. It seems that along with the progressing rate of information flow, emergence of new financial instruments and searching for new forms of creating value, this process is irreversible. Financialization is also applicable to the field of agribusiness. The specific traits of the agricultural sector - in particular, one of its production factors, that is, land - have resulted in growing interest of investors in directing uncommitted cash to this sector. A typical trait of financialization of agribusiness is purchase of land, which allows for reduction of investment risk, at the same time offering security against inflation. Research shows that financialization in agribusiness results not only from commitment of cash by investors representing other sectors, but also partially by farmers themselves.
\end{abstract}

\section{INTRODUCTION}

Financialization of economy has become a fact. The recent economic crisis (which started in 2008, and even earlier - in 2007) has proven that speculation on financial markets, excessive indebtedness of single persons and the entire economies, as well as unfounded optimism of investors may end up with bursting of the economic bubble. As a result, the scale of financial operations and instruments is so enormous that consequences of the crisis spread to economies of individual countries and globally - they are felt in many distant corners of the world. The move developed the economy and the more it is based on debt and generating additional value from financial operations, the more painful and extensive are the consequences of bursting of the economic bubble, and thus - the effects of the crisis. A decade will soon pass since the last economic crisis. Many economies have managed to recover from its painful consequences; many others are still rebuilding their development potential. A the financial crisis has been associated with many authors with financialization of economy, treating this process as the cause of financial problems of economies on the global scale, it seems interesting to determine whether any areas of economic life are resistant to the phenomenon of financialization, and thus less exposed to the risk of a crisis (and its consequences). Observation of various economies leads to a conclusion that those countries, in which capital market are smaller, and business activity is less based on debt, are less susceptible to the consequences of financial crisis. On the other hand, among many 
different sectors, agribusiness seems to be the one, which is less prone to financialization, or at least less susceptible to effects of financialization of economy.

The objective of this study is to present the process of economic financialization from the perspective of agribusiness. To check whether agribusiness is more resistant to effects of excessive indebtedness and to crisis threats. In order to achieve this objective, literature studies have been conducted and comparative and descriptive synthesis has been applied. The research results have been presented in descriptive and graphic form.

\section{THE NATURE OF FINANCIALIZATION}

Taking into account the already broad literature on financialization of economy, it can be considered 0 to put it simple - that financialization consists in increase in significance of financial operations in economic life.

According to Krystyna Mitręga-Niestrój, "Transmission of crisis from the financial sphere to reality has taken place through various channels, and the process was complex and accompanied by feedback effects. The crisis was particularly strongly experienced by the banking sector, which is of key importance for the functioning of the sphere of reality on the scale of individual countries and on the international scale; therefore, the crisis had some strong negative consequences for enterprises and households" [Mitręga, Niestrój 2012, p. 159]. In studies focused on financialization of economy, one of the basic flaws of this phenomenon is considered to be separation of financial operations from the sphere of reality. On the other hand, the effects of the financial crisis were painful for this sphere, illustrating a strong correlation between financialization of economy and the sphere of reality, or, rather, a strong dependence of the latter on the financial sphere.

Jarosław Michał Nazarczuk believes that "relatively high resistance has been shown by sectors focused mainly on domestic production of essential goods, or commodities, for which demand is relatively less flexible in relation to the price - such as the food industry" [Nazarczuk 2013, p. 83].

Katarzyna Puchalska stated that "Despite slowing down of the FDI inflow rate in years 2008-2009, the FDI processes taking place in Poland should be considered to be favorable"[Puchalska 2012, s. 101]. At the same time, it should be underlined that the food industry has been considered to be relatively resistant to crisis phenomena [Franc-Dąbrowska, Porada-Rochoń 2010, s. 28].

Quoting World Development Movement 2011, A. Haroon Akram-Lodhi states that in reality, financial speculations using derivative instruments have dominated the global financial markets of agricultural raw materials. The assets in these markets have increased from USD 65 billion in 2006 to USD 126 billion in 2011, while the share of futures contracts on the market in Chicago, controlled by speculators, increased from 12\% in 1996 to $60 \%$ in 2011 [Akram-Londhi 2014, p. 223].

According to David Burch and Geoffrey Lawrence, the financialization process also exerts impact on the entire food chain and the agri-food chain, as well as retail trade and catering services [Burch, Lawrence 2012, s. 247]. This is consistent with the findings of Sarah J. Martin and Jennifer Clapp, who state that in the period of intensification of financial operations, a substantial role is played by private financial entities and their involvement in the agricultural sector. Financialization is perceived as a component of capitalism's logic, which aims to make profit on business activity, including agriculture. A substantial 
role in financialization of the agribusiness sector has been played by the state, creating institutions to support agriculture, including in form of loans [Martin, Clapp 2015, p. 556].

Financialization has been perceived as a new phenomenon. An interesting conceptualization has been proposed by Thomas Lagoarde-Segot, who has pointed to the correlation between financialization of economy and the sphere of reality. He is of opinion that a key role in changes in the financial sector is played by liberalization of reforms, the speed of financial transactions, speculative trade and securitization, as well as complexity of informational and geopolitical networks. In the sphere of reality, key changes are associated with increasing income inequalities, increased leverage, concentration of financial and material assets and dominance of stockholders [Lagoarde-Segot 2017, p. 114].

Agribusiness fits well into the process of financialization of economy, in particular, because of the European Union's extensive agriculture support programme, focused, in particular, on agricultural income. Analyzing the new economic conditions of the common agricultural policy (CAP), Andrzej Czyżewski and Sebastian Stępień decided that the future reforms should be aimed at continuing support for the agricultural sector in terms of the volume of financial flows. The cash distribution system should be changed [Czyżewski, Stępien 2017, p. 687]. According to Jerzy Wilkin, it is not easy to determine the limit of farm size ${ }^{1}$, which would provide for an economic and social justification for exclusion of specific groups of farms from the public support system [Wilkin 2009, p. 17]. This is a significant problem, due to enrichment of owners of large agricultural farms, and thus the possibility of using the funds obtained for other purposes, not necessarily related to agriculture. Thus, space is created for financialization of agriculture (which has also been confirmed by research conducted by Sippel, Larder and Lawrence). The issue of support for agriculture has been discussed by Ryszard Kata in his studies - he claimed that farmers were interested mainly in preferential loans and - to a lesser extent-commercial bridging loans [Kata 2012, p. 245]. According to Wojciech Józwiak: "The support, from which farms in EU member states benefit, exerts positive impact on social and economic development of rural areas. "This fact is all the more important as arable land constitutes almost one half of the area of the European Union. Therefore, agricultural producers exert substantial impact on protection of natural resources [Józwiak 2017, p. 7].

According to Tania Salerno, financialization of agriculture has increased in the recent years ${ }^{2}$. This is due to sale and purchase of agriculture-related products, agricultural commodities and lands by banks, investment funds and enterprises engaged in trade of agricultural products [Salerno 2014, p. 1709], [similarly, Sippel, Larder, Lawrence 2017, p. 251]. In addition, Sarah Ruth Sippel, Nicolette Larder and Geoffrey Lawrence have pointed to a significant issue of the role played by arable land in shaping of investment portfolios - in the financialization process, it has become a significant component, securing the financial condition of investors (protecting them from inflation) [Sippel et al. 2017, p. 252]. Interestingly, farmers were not passive participants of financialization of agricultural land - some of them participated in the process [Sippel et al. 2017, p. 257].

One has to agree with the opinion of Aleksander Gorzelak and his team that it is difficult to assess the agricultural policy of the European Union simply from the perspective of supporting investments and innovations in the agricultural sector. Such objectives were not assigned directly to this policy, and their achievement was, in fact, "accidental" [Gorzelak

Agricultural farm size and subsidies dependent on such size (annotation by JFD).

These observations should be perceived more broadly as agribusiness, as they pertain to the environment of agriculture, processing in the agricultural sector, as well as trade. 
et al. 2017, p. 8]. The same team of researchers has pointed to the interesting phenomenon of a multiplier effect of the CAP, where availability of loan warranties or subsidies to loan interest rates generates substantial multiplier effects: cash multiplier, catalyzing effect and Keynesian multiplier and accelerator [Gorzelak et al. 2017, p. 16]. Relatively easier access to loans (thanks to support instruments) makes it possible for agricultural entrepreneurs to increase the scale of financing, taking advantage of financial leverage. Taking into account the share of debt in financing of activity as one of the components of financialization of economy, it can be stated that this phenomenon applies to agriculture as well.

From the historic point of view - even before Poland's accession to the European Union - typically, lessees were substantially burdened with loans, and thus - financial costs. Despite the substantial financial debt, they not only managed to achieve positive financial results, but also to generate additional value, enabling them to operate and increase the self-financing level [Franc-Dąbrowska 2006, p. 4-5]. In Polish agriculture, it is not a new phenomenon to generate additional value from financial transactions (bank deposits), aiming at least at maintaining real value of equity and thus securing it against depreciation [Franc-Dąbrowska, Kobus 2012, p. 85].

\section{RESEARCH RESULTS}

Figure 1 shows a map of the world according to changes in the GDP in year 2009. The good condition of Poland in the period following immediately the financial crisis of 20072008 is well visible. As it has been shown by the experience of the last decade, also in the later period, the situation in Poland did not deteriorate, and the financial crisis, spreading with painful consequences to the countries of North America, Canada, Europe and Asia, was not burdensome for Poland. Financialization of economy has been listed as one of the reasons of the last financial crisis. One of the reasons why Poland did not suffer so much from effects of the crisis is considered to be the relatively low level of financialization of economy. It seems, however, that it was a transitional period, and the scale of financial transactions, their value and the share of debt in financing of business activity, as well as everyday life, have started to increase.

One of the factors indicating the economic condition, as well as, potentially, the scale of financialization (as these processes are more intense in richer countries) is the GDP per capita. In order to illustrate the situation in Poland from a perspective of forty years, figure 2 presents GDP per capita according to current prices (expressed in American dollars).

It has been found that the situation of Poland, expressed as gross domestic product per capita (in current prices) indicates a strong upwards trend, and the pace of growth increased first in 1990 along with commencement of the systemic transformation in Poland, and then faster GDP per capita growth can be observed after year 2006. This clearly indicates that Poland is becoming richer (however, pauperization of the society has to be kept in mind), and thus financialization can be expected to become increasingly visible. Interestingly enough, Global Financial Stability Report shows that some of the emerging markets have used the foreign inflows to build some buffer reserves. Included in this group are Southern Africa, Turkey, Columbia, Mexico, Chile, India, Poland, Brazil, Indonesia, China and Russia [Global... 2017, p. 25].

Another indicator of impact of financial crisis on economy is the level of change in retail sales per capita. Figure 3 presents this indicator for individual provinces. The least 

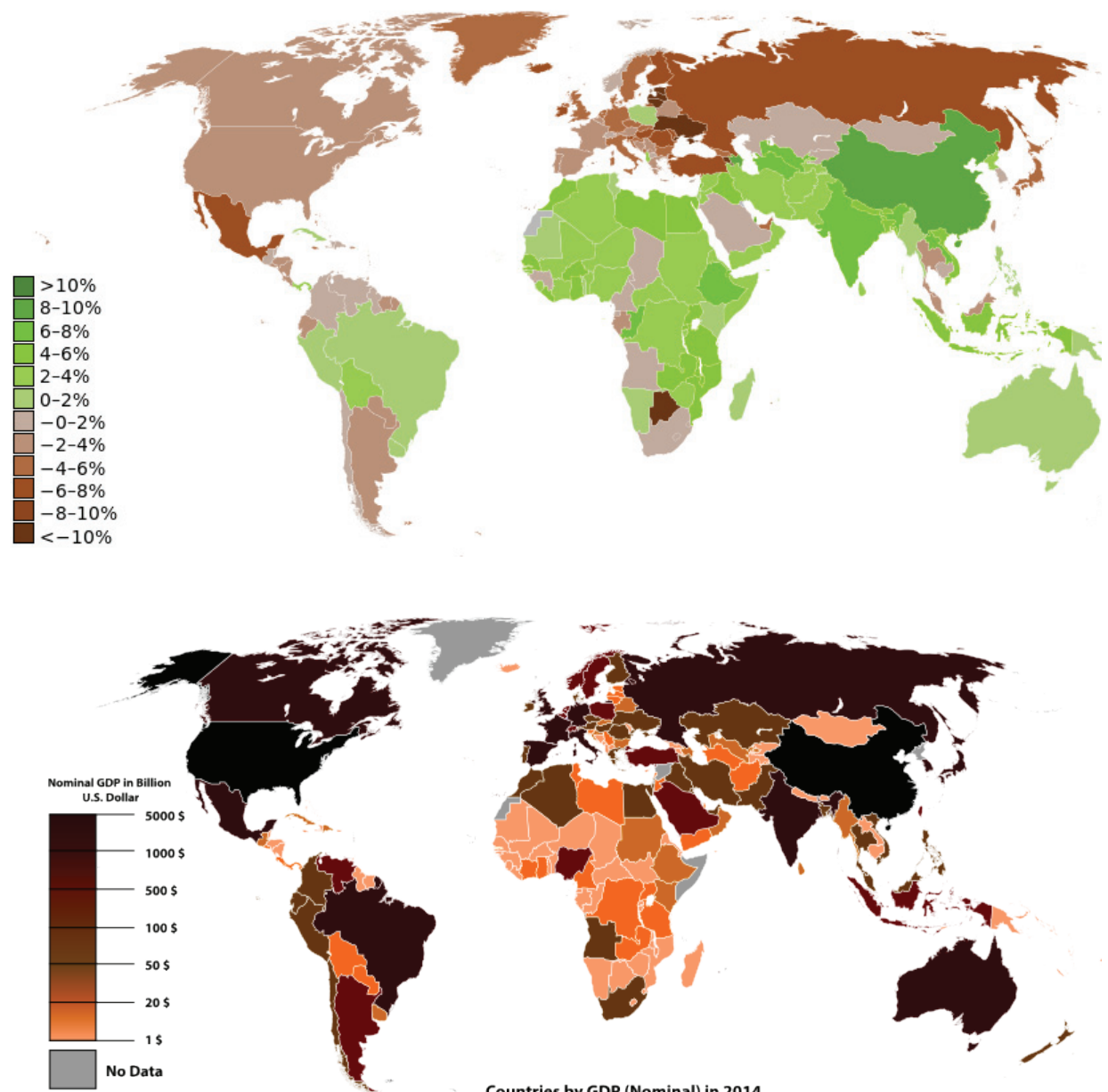

Countries by GDP (Nominal) in 2014

Figure 1. World maps by GDP changes in 2007-2009 [\%] and nominal GDP in 2014 [USD] Source: [https://pl.wikipedia.org/wiki/Kryzys_finansowy_od_2007, https://pl.wikipedia.org/wiki/ Lista_pa\%C5\%84stw_\%C5\%9Bwiata_wed\%C5\%82ug_PKB_, 30.12.2017]

favorable conditions were observed in the southern and southeastern part of Poland, although in the central, western, eastern and northern part of Poland, it should be considered that the retail sale indicator per capita was positive, and in some provinces it was relatively high $(12.6 ; 15.6 ; 18.5 \%)$.

Considering these trends (presented in figures 1 and 2) in the light of information on indebtedness of the Polish agricultural entrepreneurs, it can be assumed that financialization processes are taking place in this sector as well. Research on debt of enterprises, including agricultural enterprises, conducted by Danuta Zawadzka and Ewa Szafraniec-Siluta indicates that these entities financed $27 \%$ of their fixed assets with external capital, while use of trade credit reached the level of $30 \%$ (which is typical for agricultural enterprises, 


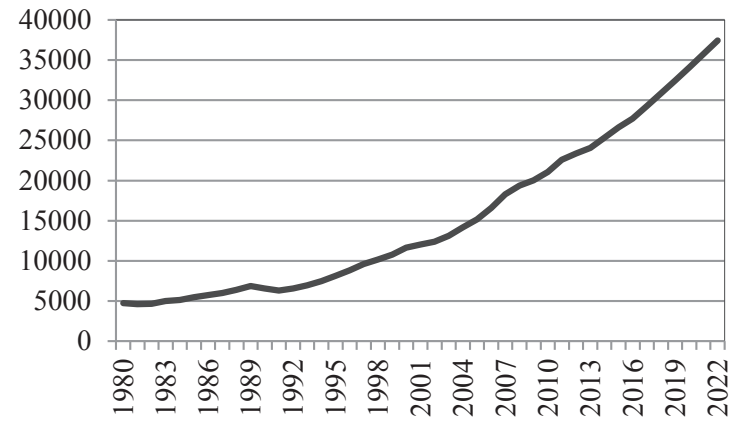

Figure 2. Gross domestic product per capita, current prices [USD]

Source: own studty based on: [International Monetary

Fund, http://www.imf.org/ external/pubs/ft/weo/2017/02, 30.12.2017]

and the phenomenon was analyzed thoroughly by Danuta Zawadzka [2009]). It can thus be concluded that financialization of Polish economy, including the sphere of agribusiness, has become a fact. However, it has not become very clearly defined, which is due to conservative behaviors of farmers, who avoid commercial loans and rarely speculate on capital markets.

Particularly significant in the process of financialization of agribusiness is the issue of buyout of land. According to the Draft report on the current state of concentration of agricultural land in the EU: how to make land more available for farmers?: "The period of low interest rates, which has prevailed since the economic crisis, is one of the reasons for the phenomenon of "resorting to real value", or, in other words, land. Thus, investors representing other trades are also interested in purchase of land." [Draft... 2016, p. 8]. Similar observations have been included in the Opinion of the European Economic and Social Committee of 21 January 2015 entitled 'Land grabbing - a wake-up call for Europe and an imminent threat to family farming', It indicates that factors favorable for mass buyout of agricultural land include progressing globalization, accompanied by free movement of capital, as well as the possibility to speculate on increase in the value of arable land [Opinion ... 2015, p. 1]. Undoubtedly, another area associated with financialization of

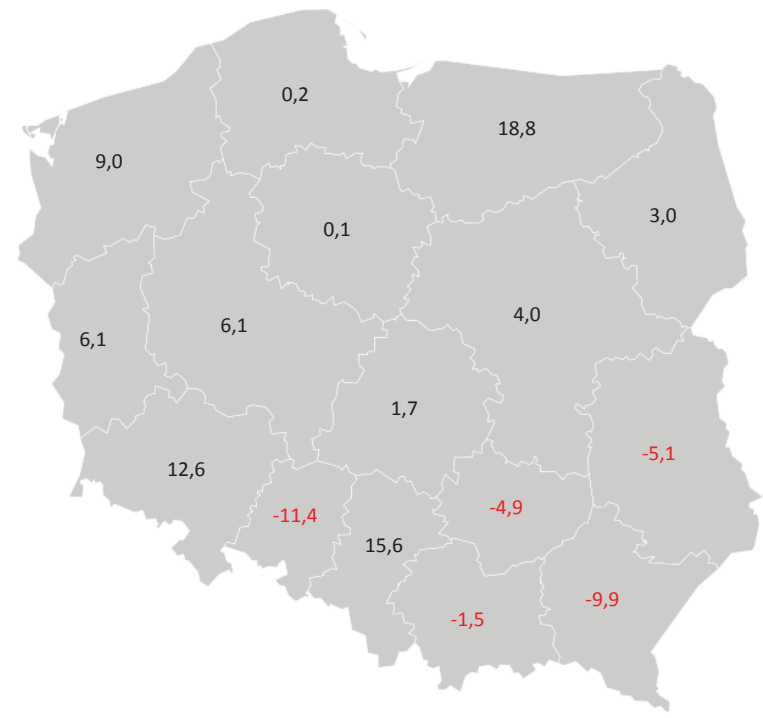

Figure 3. Map of Poland according to changes in retail sales per capita [\%]

Source: own study based on [Nazarczuk 2013, p. 84 oraz Mapa Polski https:// www.amcharts.com/ svg-maps/?map=poland, 21.11.2017]. 
agribusiness - apart from the issue of increase in indebtedness of farmers and agricultural entrepreneurs - is the problem of land buyout. This issue requires a thorough analysis from the perspective of financialization in agribusiness.

\section{CONCLUSIONS}

Financialization of economy progresses over time. It is associated with increase in the scale, value and pace of financial transactions, as well as increase in the level of indebtedness of individuals, economic entities and the entire economies. This process results in increase of the risk - in particular, financial risk - and by some, it is perceived as the reason for the last financial crisis. Undoubtedly, some industries are more susceptible to the financialization process; in others, the process is progressing more slowly. It seems that it has been progressing in agribusiness as well. Probably, it concerns rather large entities engaged in processing and not single farms; however, as it has been indicated by research results, arable land can be perceived as a valuable asset in the financialization process, purchased to limit the risk and to obtain protection against inflation. Thus, financialization of agriculture and the sphere of agribusiness is, in fact, independent of the natural production processes, typical for the trade. It also seems that the process will progress along with continuation of support offered within the framework of assistance programmes of the Common Agricultural Policy and availability of subsidies and preferential loans. This area of financial support for agriculture should be perceived as a component of financialization of the sphere of agribusiness.

\section{BIBLIOGRAPHY}

Akram-Lodhi Haroon A., 2014: The antinomies of food financialization, "Dialect Anthropol", 38, p. 219-224.

Burch David, Geoffrey Lawrence, 2013: Financialization in agri-food supply chains: private equity and the transformation of the retail sector, "Agric. Hum. Values", 30, p. 247-258.

Czyżewski Andrzej, Sebastian Stępień, 2017, Nowe uwarunkowania ekonomiczne wspólnej polityki rolnej (WPR) Unii Europejskiej, „Ekonomista” 6, p. 675-697.

Franc-Dąbrowska Justyna, 2006: Poziomy wyniku finansowego miara sytuacji finansowej przedsiębiorstw w warunkach rozwoju zrównoważonego, „Zeszyty Naukowe Akademii Rolniczej we Wrocławiu. Rolnictwo", 87(540), p. 149-156.

Franc-Dąbrowska Justyna, Małgorzata Porada-Rochoń, 2010, Bezpośrednie inwestycje zagraniczne-perspektywa międzynarodowa, „Przegląd Organizacji”, 4, p. 28-32.

Franc-Dąbrowska Justyna, Paweł Kobus, 2012: Koszt kapitału własnego - dylematy wyceny, „Zagadnienia Ekonomiki Rolnej”, 1(330), p. 77-89.

Global Financial Stability Report. Is Growth at Risk? 2017: International Monetary Fund, Publications Services P.O. Box 92780, Washington, DC 20090, U.S.A.

Gorzelak Aleksander, Justyna Herda-Kopańska, Jacek Kulawik, Michał Soliwoda, Barbara Wieliczko, 2017: Kontrowersje wokół europejskiej wartości dodanej tworzonej przez WPR, „Zagadnienia Ekonomiki Rolnej”, 1(350), p. 3-28.

Józwiak Wojciech, 2017: Wspólna unijna polityka rolna po 2020 roku, „Zagadnienia Ekonomiki Rolnej”, 3, p. 3-18.

Kata Ryszard, 2012: Przestanki oraz mikroekonomiczne determinanty korzystania przez rolników z kredytów bankowych, „Roczniki Ekonomiczne Kujawsko-Pomorskiej Szkoły Wyższej w Bydgoszczy", 5, p. 241-260.

Lagoarde-Segot Thomas, 2017: Financialization: Towards a new research agenda, "International Review of Financial Analysis", 51, p. 113-123. 
Martin Sarah J., Jennifer Clapp, 2015: Finance for Agriculture or Agriculture for Finance? "Journal of Agrarian Change", vol. 15, no. 4, p. 549-559.

Mitręga-Niestrój Krystyna, 2012: Skutki światowego kryzysu finansowego w sferze realnej-ujęcie międzynarodowe, ,Studia Ekonomiczne”, no. 122, p. 159-171.

Nazarczuk Jarosław M., 2013: Wpływ światowego kryzysu finansowego na gospodarkę Polski i jej regionów, [in] eds. R. Kisiel, M. Wojarska, Wybrane aspekty rozwoju regionalnego, Fundacja „Wspieranie i Promocja Przedsiębiorczości na Warmii i Mazurach”, Olsztyn, p. 75-89.

Opinia Europejskiego Komitetu Ekonomiczno-Społecznego w sprawie: „Masowy wykup gruntów rolnych - dzwonek alarmowy dla Europy i zagrożenie dla rolnictwa rodzinnego", (2015/C 242/03), Dz.Urz. UE, C 242/15.

Projekt sprawozdania $w$ sprawie aktualnego stanu koncentracji gruntów rolnych $w$ UE: jak ułatwić rolnikom dostęp do gruntów? (2016/2141(INI), Komisja Rolnictwa i Rozwoju Wsi, PR/1108078PL.docx.

Puchalska Katarzyna, 2012: Kryzys gospodarczy a napływ bezpośrednich inwestycji zagranicznych do Polski, [in] Nierówności Społeczne a Wzrost Gospodarczy, eds. M.G. Woźniak, Wydawnictwo Uniwersytetu Rzeszowskiego, Rzeszów, p. 93-102.

Salerno Tania, 2014: Capitalising on the financialisation of agriculture: Cargill's land investment techniques in the Philippines, "Third World Quarterly", vol. 35, no. 9, p. 1709-1727, http:// dx.doi.org/10.1080/01436597.2014.971567.

Sippel Sarah R., Nicolette Larder, Geoffrey Lawrence, 2017: Grounding the financialization of farmland: perspectives on financial actors as new land owners in rural Australia, "Agric. Hum. Values", 34, p. 251-265.

Wilkin Jerzy, 2009: Ekonomia polityczna reform Wspólnej Polityki Rolnej, „Gospodarka Narodowa”, 1-2 (209-210), XX, p. 1-25.

Zawadzka Danuta, 2009: Determinanty popytu matych przedsiębiorstw na kredyt handlowy: identyfikacja i ocena, Wydawnictwo Uniwersytetu Ekonomicznego, Poznań.

Zawadzka Danuta, Ewa Szafraniec-Siluta, 2016: Ocena zadlużenia przedsiębiorstw w Polsce-analiza sektorowa ze szczególnym uwzględnieniem przedsiębiorstw rolniczych, „Roczniki Naukowe SERiA", XVIII(6), p. 234-239.

https://pl.wikipedia.org/wiki/Kryzys_finansowy_od_2007.

https://www.amcharts.com/svg-maps/?map=poland, accessed 21.11.2017.

http://www.imf.org/external/pubs/ft/weo/2017/02, accessed:30.12.2017.

\section{Justyna Franc-Dąbrowska}

\section{FINANSOWANIE GOSPODARKI Z UWZGLEDNIENIEM AGROBIZNESU}

\section{Streszczenie}

Ufinansowienie gospodarki dokonuje się. Wydaje się, że wraz z postępem $w$ tempie obiegu informacji, powstawania nowych instrumentów finansowych i poszukiwania nowych form tworzenia wartości jest to proces nieodwracalny. Finansjalizacja dotyczy także sfery agrobiznesu. Specyficzne cechy sektora rolnego, a szczególnie czynnika produkcji jakim jest ziemia, spowodowaty zainteresowanie inwestorów skierowaniem wolnych środków pieniężnych do tego sektora. Cecha charakterystyczna ufinansowienia agrobiznesu jest zakup ziemi, która pozwala na ograniczenie ryzyka inwestycyjnego, jednocześnie stanowiąc zabezpieczenie przed inflacja. Z badań wynika, że ufinansowienie $w$ agrobiznesie dokonuje się nie tylko za sprawa angażowania środków pieniężnych inwestorów spoza tego sektora, ale także częściowo samych rolników.

Adres do korespondencji: Dr hab. Justyna Franc-Dąbrowska, prof. SGGW (orcid.org/0000-0002-5881-0343) Warsaw University of Life Sciences - SGGW

Department of Finance

Nowoursynowska Str. 166

02-787 Warsaw, tel. (22) 5934274 e-mail: justyna_franc_dabrowska@sggw.pl 